\title{
AN ANALYSIS OF METAPHOR IN ONE DIRECTION
}

\author{
ALBUM \\ Tuti Dwi Agustin \\ Amri Tanduklangi \\ Yulius Tandi Sapan \\ English Department \\ Halu Oleo University \\ Email: tutidwiagustin@gmail.com
}

\begin{abstract}
Lyrics in song are intended to send a message to the audience or music lovers. Composers use figurative language as the media to convey their message. One of the figurative languages that is mostly used in song's lyrics is Metaphor. This study was intended to investigate the types of metaphor used in One Direction Album. The objective of this study to identify the types of metaphor found in the song lyrics and to analyze metaphor meaning in One Direction song. This study adopted a descriptive qualitative research design. Three songs by One Direction had been chosen as the data of this study; Story of My Life, Steal My Girl and Drag Me Down. The data were analyzed its metaphor by using Lakoff and Johnson theory, while in investigating the meaning, Chaer's theory of contextual meaning was used. The result of the study showed that based on the three types of metaphor, structural metaphor becomes the most frequently used in the song lyrics, meanwhile 2 of 3 songs used all of the three types of metaphor; Orientation, Structural and Ontological Metaphor. In answering the second research question about the meaning of each metaphor, each lyric has been analyzed through content analysis to know the true meaning of what the song writer want to express in his/her lyrics and each lyric has different contextual meaning which is elaborated further in this study.
\end{abstract}

Keywords: Metaphor, Meaning, One Direction's Album 


\section{Introduction}

Lyric is expressions of the writer's feeling of or composed for singing. It means that lyric of a song can be written depending on someone's experiences of life such as, love, happiness, sorrow, family and friendships. To comprehend the lyric well, the readers must be able to identify words or phrases that consist of figurative languages and to find their meaning. Therefore, since studying poem is worth and interesting to do, studying song is worth and interesting too. There are some kinds of figurative language usually applied in the song by composers. To achieve the purpose of writing the lyrics, the dominant element used in the song is metaphor. Metaphor or figure of speech is used in the lyrics with aesthetic purposes in order to create a beautiful song, pleasant to hear, and helpful for the listeners to understand the information in the songs. In Summary, lyric is a fairly short poem, consisting of the utterance by a single speaker who expresses a state of mind or a process of perception, thought, and feeling.

Furthermore, song is not only used to convey a life story, but also as an amusement for the listeners. To make a song become more artistic, the composers often use figurative language to express their work. One of the types of figurative language as well as the way to make song become more artistic is Metaphor. Related to the above background, this study is aimed at analyzing the use of metaphor in song. This writer is interested in analyzing the song from One Direction because One Direction's songs are very well known throughout the world and the lyrics contain many expressions of the singer who imagine about the condition or situation that the singer had. In the other words, this study intends to know the types of metaphor in the lyric from One Direction as well as the meaning of the metaphor. The songs were Story of My Life", "Dark Me Down", and "Steal My Girl".

This study is expected to be beneficial to English Teacher and students 
since it will be useful for teaching vocabulary and listening skills for the students and it is useful for learning figurative language. In addition, it is presumed to increase student's engagement in learning because most students favor learning language through song. Moreover, this study will also give more information about figurative language, because when we study about language especially song, we will find the figurative language that mostly used in order to give a deep comprehension about the songs. This information can be used as well for teaching and learning process, especially in teaching listening and reading about figuring the metaphor of the song.

This study was focused on three types of metaphor; Structural Metaphor, Orientation Metaphor and Ontological Metaphor. Besides, this study used Contextual Meaning as the standard of investigated meaning in each metaphor.

\section{Literature Review}

Lakoff and Jhonson (1980) defined metaphor as pervasive in everyday life, not only just in language but also in thought and action. Our ordinary conceptual system, in term of thinking and acting is fundamentally metaphorical in nature. Metaphor is something that has another meaning and its main function is to understand. In other words, metaphor is part of a figurative language that compares one thing with another. Lakoff and Johnson observe that all human language uses the metaphorical meaning to communicating at different levels of abstraction from concrete reality. Lakoff and Johnson's theory is better known as the conceptual metaphor theory. Lakoff and Johnson divide metaphors into tree types: structural metaphors, orientation metaphors and ontological metaphors (Lakoof and Johnson, 1998)

According to Lakoff and Jhonson (1980), metaphor consists of three types. The first type is Structural metaphor. Structural metaphor is the concept in the form of metaphorically using another concept. This structural metaphor is based on two domains, namely the domain of the source and target domains. Structural metaphor is based on a systematic correlation in daily experience. In 
short, a metaphor in which a complex concept (mostly abstract) is presented in a more concrete term. Example: Argument is War,

The second type is orientation metaphor. It is the metaphor which is associated with spatial orientation, such as up-down, inside-out, front-rear, and many others. This spatial orientation arises from the fact that we are thinking about the body and the body to function in the physical environment. This metaphor is based on human physical experience in organizing orientation in their daily lives, such as up-down measured by physical human experience. Orientation metaphors reflect different spatial concept in physical experience or culture of the people. Therefore metaphor orientation is different in every culture because every culture has a difference from what is in the mind. Orientation metaphor gives a concept a spatial orientation. In summary, it is a metaphor that involves an orientation. For example: "Speak up" and "Keep your voice down".

The last type is ontological metaphor which is defined as a metaphor views events, activities emotions, and ideas as entities and substance. Example: "the mind is machine" in the phrase "My mind just isn't operating today". Ontological metaphor is a metaphor for conceptualizing the thoughts, experience and processes it into something which is more abstract thinking about the physical properties. In other words, Ontological metaphor considers abstract noun as concrete nouns.

Furthermore, contextual meaning is also used in this study. Contextual meaning is the meaning of a lexeme or word inside a context (Chaer 1994). Context is a situation that occurs depends on whether phrase or sentence appears. A contextual definition is also a definition in which the term is used by embedding it in a larger expression containing its explanation. In the same side, Mansoer Pateda (2010) stated contextual meaning could be regarded as a situational meaning. It appears as a result of the relationship between speech and context (2010: 116).

Requejo (2007) stated that contextual meaning is that whenever a linguistic expression cannot be straightforwardly interpreted, we turn to context 
to find some extra cues in order to get the right meaning. It means that, context is used here in its broadest sense, since anything around a particular word can potentially affect its meaning. In other words, when a word is used in a piece of text, it usually has only one meaning, but sometimes it has meaning variation depending on the topic of discussion. We must know the hidden meaning of word to provide useful information for understanding meaning in a sentence or phrase based on context meaning. Furthermore, contextual meaning is used in this paper as the standard to define the meaning of each selected metaphor.

Research Method

This study used descriptive qualitative method to describe phenomenon of figurative language, types of metaphor used in lyric song from One Direction. It used qualitative method through an inductive approach in the analysis because the data were not in the form of numbers but words in describing the kinds of metaphor used in One Direction songs lyric.

In this study, the writer was the main instrument in collecting the required data by applying the theories, interpreting the data based on the general contextual meaning of the song lyrics, interpreting the data based on the way of One Direction expresses figurative language and the last making conclusion based on data analysis.

Moreover, the writer used qualitative data through content analysis by selecting the data which were obtained from various sources and information. The writer firstly listened to the songs that were analyzed, and then read the lyrics carefully and noted any songs containing a figurative speech metaphor. FINDINGS

The writer analyzed the types of figurative language that were found in "Story of My Life", "Dark Me Down", and "Steal My Girl" by One Direction. Types of Metaphor in "Story of My Life"

The writer analyzed the song lyric of "Story of My Life" by One Direction. It was conducted to find out the figurative language use in that song. The 
figurative language used in that song can be seen in table 4.1, meanwhile the meaning of each metaphor will be presented to answer the next research problem.

Table 1. Type of Metaphor in Story of My Life

\begin{tabular}{|l|l|l|}
\hline No & Song Lyric & Type of Metaphor \\
\hline 1 & I leave my heart open (Verse1, line \#2) & $\begin{array}{l}\text { Ontological } \\
\text { Metaphor }\end{array}$ \\
\hline 2 & Until she's broken inside (Chorus, line \#5) & $\begin{array}{l}\text { Orientation } \\
\text { Metaphor }\end{array}$ \\
\hline 3 & $\begin{array}{l}\text { But it stays right here in its cage (Verse } \\
\text { line 2, \#4) }\end{array}$ & $\begin{array}{l}\text { Structural } \\
\text { Metaphor }\end{array}$ \\
\hline 4 & $\begin{array}{l}\text { I'll see us in the light up on the hill (Verse } \\
2, \text { line \#6) }\end{array}$ & $\begin{array}{l}\text { Orientation } \\
\text { Metaphor }\end{array}$ \\
\hline 5 & $\begin{array}{l}\text { Although I am broken, my heart is } \\
\text { untamed still (Verse 2, line \#7) }\end{array}$ & $\begin{array}{l}\text { Structural } \\
\text { Metaphor }\end{array}$ \\
\hline 6 & $\begin{array}{l}\text { The fire beneath my feet is burning bright } \\
\text { (Pre-Chorus, line \#2) }\end{array}$ & $\begin{array}{l}\text { Orientation } \\
\text { Metaphor }\end{array}$ \\
\hline 7 & $\begin{array}{l}\text { The way that I've been holding on so tight } \\
\text { With nothing in between( Pre-Chorus, line } \\
\text { \#3 and \#4) }\end{array}$ & $\begin{array}{l}\text { Orientation } \\
\text { Metaphor }\end{array}$ \\
\hline 8 & $\begin{array}{l}\text { And time is frozen (Chorus, line \#3) } \\
\text { But, baby, running after you } \\
\text { Is like chasing the clouds (Bridge, line \#2) } \\
\text { metaphor }\end{array}$ & $\begin{array}{l}\text { Structural } \\
\text { Metaphor }\end{array}$ \\
\hline
\end{tabular}

Based on the above table, it is clearly shown that the lyrics "Story of My Life" by One Direction used all the three types of Metaphor; Structural Metaphor, Orientation Metaphor and Ontological Metaphor. It leads us to the conclusion that this song is full of metaphor meaning. The writer expresses their feeling or what they want to confess to the listener through the using of metaphor. For example, the writer used the lyrics "But baby running after you/ is like chasing 
the clouds". By using this lyric, the writer tried to express that it is nearly impossible to get what he/she needs in his/her life. The writer used the structural metaphor to explain one complex concept by using more concrete term metaphorically.

Type of Metaphor in "Steal My Girl”

Table 2. Type of Metaphor in Steal My Girl

\begin{tabular}{|l|l|l|}
\hline No & Song Lyric & Type of Metaphor \\
\hline 1 & $\begin{array}{l}\text { Couple billion in the whole wide world } \\
\text { (Chorus, line \#3) }\end{array}$ & Structural Metaphor \\
\hline 2 & $\begin{array}{l}\text { Everybody wanna take her heart away } \\
\text { (Chorus, line2) }\end{array}$ & Ontological Metaphor \\
\hline 3 & $\begin{array}{l}\text { Kisses like cream, her walk is so mean } \\
\text { (Verse 2, Line \#2 and \#4) }\end{array}$ & Structural Metaphor \\
\hline 4 & $\begin{array}{l}\text { And every jaw drops when she's in those } \\
\text { jeans (Verse, line\#3 and \#4) }\end{array}$ & Structural Metaphor \\
\hline 5 & $\begin{array}{l}\text { I don't exist, if I don't have her. The sun } \\
\text { doesn't shine, the world doesn't turn, (Verse } \\
2, \text { line \#5 to \#8) }\end{array}$ & Ontological Metaphor \\
\hline
\end{tabular}

Based on the above table, it is clearly shown that the lyrics "Steal My Girl" by One Direction only used two types of Metaphor; Structural Metaphor, and Ontological Metaphor. Moreover, from all the lyrics, only 5 were indicated as metaphor. This may also leads us to the conclusion that this song uses less metaphor than the other songs and may have more figurative languages which were not covered in this study.

Type of Metaphor in "Drag Me Down"

Table 3. Type of Metaphor in Drag Me Down

\begin{tabular}{|l|l|l|}
\hline No & Song Lyric & Type of Metaphor \\
\hline 1 & I've got fire for a heart, (Verse 1, line \#1) & $\begin{array}{l}\text { Structural } \\
\text { Metaphor }\end{array}$ \\
\hline
\end{tabular}




\begin{tabular}{|l|l|l|}
\hline 2 & $\begin{array}{l}\text { I got a river for a soul, and baby you're a boat } \\
\text { (Verse 1, line \#4 and \#5) }\end{array}$ & $\begin{array}{l}\text { Structural } \\
\text { Metaphor }\end{array}$ \\
\hline 3 & $\begin{array}{l}\text { All these lights, they can't blind me (Chorus, } \\
\text { line \#3) }\end{array}$ & $\begin{array}{l}\text { Ontological } \\
\text { Metaphor }\end{array}$ \\
\hline 4 & $\begin{array}{l}\text { If I didn't have you I'd never see the sun (Pre- } \\
\text { Chorus, line \#3) }\end{array}$ & $\begin{array}{l}\text { Ontological } \\
\text { Metaphor }\end{array}$ \\
\hline 5 & $\begin{array}{l}\text { When no one else was ever behind me (Chorus, } \\
\text { line \#2) }\end{array}$ & $\begin{array}{l}\text { Orientation } \\
\text { Metaphor }\end{array}$ \\
\hline 6 & $\begin{array}{l}\text { All my life, you stood by me (Chorus, line \#1) } \\
\text { Ontological } \\
\text { Metaphor }\end{array}$ \\
\hline 7 & $\begin{array}{l}\text { With your love, nobody can drag me down } \\
\text { (Chorus, line \#4) }\end{array}$ & $\begin{array}{l}\text { Orientation } \\
\text { Metaphor }\end{array}$ \\
\hline
\end{tabular}

Based on the above table, it is clearly shown that the lyrics "Drag $\mathrm{Me}$ Down" by One Direction used all the three types of Metaphor; Structural Metaphor, Orientation Metaphor and Ontological Metaphor. It leads us to the conclusion that this song is full of metaphor meaning. The writers express their feeling or what they want to confess to the listener through the use of metaphor.

The Meaning of Metaphor

After analyzing and categorizing each lyric into several metaphors, the next analysis is to define the meaning of each song based on the used metaphor. In this case, the meaning used in this paper is Conceptual Meaning. There are 21 metaphors found in "Story of My Life", "Dark Me Down", and "Steal My Girl" of One Direction. These lyrics then categorized into Ontological Metaphor, Orientation Metaphor and Structural Metaphor. As been mentioned in the previous paragraph, the contextual meaning of these metaphor were analyzed and divided into three section based on each type of metaphor.

The Meaning of Ontological Metaphor

Example Data:

"Written in these walls are the stories that I can't explain I leave my heart open 
But it stays right here empty for days"

(Story of My Life: Verse 1 Line 1-3)

In this paragraph, the writer explains that their 'real self' is within the walls of their family's home. Even though they can be and go whatever they want, at some point they just want to stay a little bit the way they were before being famous. Here they explain that with their families, they see the real person they are. their real 'self' doesn't change and even if they go somewhere else, their heart stays with their moms imprisoned with their love. "I leave my heart open" means that they are ready to receive any love besides the family. But their heart will forever stay with the family.

Moreover in this context, "I leave my heart open" is similar to "I leave the door open". In other words, the word "heart" is expressed similarly with "door" which can be opened or closed, depends on the owner choice. The use of the word depends on the context of what is being expressed. Since this song is talking more about love and family, therefore the word "heart" is appropriate to be used in this context.

The Meaning of Orientation Metaphor

Example Data

\author{
The story of my life \\ I give her hope \\ I spend her love \\ Until she's broken inside \\ (Story of My Life, Chorus Line 6-9)
}

The writers talk about the unconditional love that their moms have for them and how the little moments they spend together are more meaningful now and how they would like those moments to last longer. They convince her mom that is for a good reason that they are leaving, knowing that their mom's heart will broke inside after giving it all for them It is proven by the previous lyrics and by reading the whole lyrics of the song.

Moreover, the use of word "broke" in the lyric "Until she's broke inside" is different from the word "broke" in the sentence "I broke my glasses yesterday". "broke my glasses yesterday", means we made the glasses into pieces or more 
from the original form. However, in the lyrics, "Broke" means "feeling hurt" because theay are talking about heart or feeling.

The Meaning of Structural Metaphor

Example Data:

Written on these walls are the colours that I can't change

Leave my heart open

But it stays right here in its cage

(Story of My Life, Verse 2)

Data 1 shows that the writers try to express their feeling by saying "But it stays right here in its cage". This implies that even if they go somewhere else, their heart stays with their moms imprisoned with their love. Moreover, the use of word "cage" in the lyrics is different from the sentence "I stay in a cage for one night". Since the song is mostly talking about family and their loves one, so "cage" refers to them. In other words, their true feeling and love will be forever with them.

Discussion

Types of Metaphors Found in this research

According to the result found in each song, it is found that the three types of metaphor (Structural, Orientation and Ontological) were found in two songs of One Direction; Story of My Life and Drag Me Down. Meanwhile, in Steal My Girl only have 2 types of metaphor; Structural and Ontological Metaphor. This indicates that not all of the One Direction's song used the three types of metaphor in their lyrics to replace the real meaning they want to express. Sometimes, there are also another figurative language used in their song, such as personification and etc. Similar result has also been found in Lestari (2017) who has also conducted the same research to find the metaphor in Green Day's song. In her research, she found that that all types of metaphor are found in the data. 
Moreover, Lestari (2017) also found that ontological metaphor as the most frequently used type of metaphor based on Lakoff and Johnson theory. It is similar with the current study which found that one of the One Direction song "Drag Me Down" which has 3 ontological metaphor of 7 metaphor found in this song. Meanwhile, if the total of metaphor found is compiled, structural metaphor is the most frequently used in the three songs analyzed in this current research, which is contradictive with the result form Lestari (2017). Structural metaphors are the prevalent type of metaphors in the data and as Lakoff and Johnson (1980) explain, these provide the richest source for elaborating concepts (p. 61). This can be seen in the analysis as well.

The Meaning of Each Metaphor

Related to this current study, Pateda (2010) stated contextual meaning could be regarded as a situational meaning. It appears as a result of the relationship between speech and context (2010: 116). Contextual meaning is the meaning according to the context. Contextual meaning is the meaning according to the context in a sentence. As has been stated previously, Requejo (2007) stated that contextual meaning is that whenever a linguistic expression cannot be straightforwardly interpreted, we turn to context to find some extra cues in order to get the right meaning. It means that, context is used here in its broadest sense, since anything around a particular word can potentially affect its meaning. In other words, when a word is used in a piece of text, it usually has only one meaning, but sometimes it has meaning variation depending on the topic of discussion. Therefore, we must know the hidden meaning of word to provide useful information for understanding meaning in a sentence or phrase based on context meaning.

\section{Conclusion}

Related to the first research question, it is found that the three types of metaphor (Structural, Orientation and Ontological) were found in two songs of One Direction; Story of My Life and Drag Me Down. Meanwhile, in Steal My Girl only have 2 types of metaphor; Structural and Ontological Metaphor. 
This indicates that not all of the One Direction's song used the three types of metaphor in their lyrics to replace the real meaning they want to express. Sometimes, there are also another figurative language used in their song, such as personification and etc. In conclusion, the one direction song mostly used structural metaphor in their songs. It is proven by the three songs used as the sample of this study. From the 21 metaphor found in the three songs of one direction, nine of them are structural metaphor or almost half of them categorized as structural metaphor.

Meanwhile, in the second research question, the meaning of metaphors also revealed from the analysis process, It is only focus to find the contextual meaning. It is because song lyrics have the communicative value of an expression over and above its purely contextual content. Moreover, it is something that goes beyond mere referent of a word and hints at its attribute in the real word. It is also regarded as incidental, comparatively unstable, in determinant, open ended, variable according to age, culture, and individual. Metaphor also shows the concept and point of view from this band toward the actual situation.

After analyzing the data and summarizing the conclusion, it is suggested for researchers who want to do a research in semantics approach, to deeply explore about conceptual Metaphor theory, for instance, observing other media or clues such as poem to find the types of metaphor. In the song lyrics, theory of conceptual metaphor used to convey the concept of metaphor that leads to understand the meaning of metaphor. Meanwhile, in poem we can also use this theory in order to know what the poem is actually talking about. Therefore, the writer hopes that there will be other writers who will conduct the research using conceptual metaphor as a theory.

\section{REFEERENCES}

Chaer, A. (1994). Linguistik Umum. Jakarta: Rineka Cipta. 
Lakoff, G. and Jhonson, M. (1980) Conceptual Metaphor in Everyday Language. Journal of Philosophy, 77(8): pp. 453-486, http://WWW.jstor.Org/stable/2025464 /

Lestari, W (2017) Metaphor in the Song Lyrics of GreenDay. Unpublished Thesis: Syarif Hidayatullah State Islamic University.

Mansoer Pateda (2010). Semantic Leksikal. Jakarta: PT. Rineka Cipta.

Requejo. (2007). The Role of Context in Word Meaning Construction: A Case Study. International Journal of English Studies. IJES, 7(1). 